\title{
NEZASTARIJEVANJE RATNOG PROFITERSTVA U RALJAMA NAČELA ZAKONITOSTI, PRAVEDNOSTI I UČINKOVITOSTI
}

Prof. dr. sc. Leo Cvitanović*

Prof. dr. sc. Davor Derenčinović**

Doc. dr. sc. Marta Dragičević Prtenjača ${ }^{* * *}$
UDK: 343.291:343.353(497.5)

$342.565 .2(497.5)$

DOI: 10.3935/zpfz.69.4.01

Izvorni znanstveni rad

Primljeno: kolovoz 2019.

Promjenama Ustava Republike Hrvatske iz 2010. godine, kojima je, medu ostalim, u hrvatski ustavnopravni $i$ kaznenopravni poredak uvedeno nezastarijevanje kaznenih djela ratnog profiterstva $i$ kaznenih djela počinjenih u procesu pretvorbe $i$ privatizacije te donošenjem Zakona o nezastarijevanju kaznenih djela ratnog profiterstva $i$ kaznenih djela iz procesa pretvorbe i privatizacije kao implementacijskog propisa 2011. godine, potaknute su brojne polemike u hrvatskoj stručnoj javnosti o tome zadire li se tim promjenama, koje su bez presedana ne samo u hrvatskom već $i$ u komparativnom pravu, u temeljna načela kaznenog prava $i$ jesu li one $u$ skladu s načelom vladavine prava. Proponenti tih promjena isticali su kako je njihova svrha bila ispravljanje nepravdi do kojih je dovelo neprocesuiranje ratnog profiterstva u tranzicijskom razdoblju (u radu se termin "ratno profiterstvo" koristi kao generički za kaznena djela koja ne zastarijevaju na temelju članka 31. stavka 4. Ustava Republike Hrvatske i Zakona o nezastarijevanju kaznenih djela ratnog profiterstva $i$ kaznenih djela počinjenih u procesu pretvorbe i privatizacije) $i$ osna-

* Dr. sc. Leo Cvitanović, profesor Pravnog fakulteta Sveučilišta u Zagrebu, Trg Republike Hrvatske 14, Zagreb; leocvitanovic@gmail.com;

ORCID ID: orcid.org/0000-0001-8383-5262

** Dr. sc. Davor Derenčinović, profesor Pravnog fakulteta Sveučilišta u Zagrebu, Trg Republike Hrvatske 14, Zagreb te predsjednik Akademije pravnih znanosti Hrvatske, Trg Republike Hrvatske 14, Zagreb; davorderen@yahoo.com;

ORCID ID: orcid.org/0000-0002-4146-7905

*** Dr. sc. Marta Dragičević Prtenjača, docentica Pravnog fakulteta Sveučilišta u Zagrebu, Trg Republike Hrvatske 14, Zagreb; marta.dragicevic@pravo.hr;

ORCID ID: orcid.org/0000-0001-9666-4765 
živanje nacionalnog gospodarstva povratom nezakonito stečene imovinske koristi. S druge strane, oponenti, među kojima su i autori ovoga rada, isticali su kako je takav način ispravljanja "tranzicijske nepravde" u svojoj osnovi bio pogrešan, $u$ suprotnosti s brojnim aspektima načela legaliteta, ali i načela efektiviteta, jer je nedvojbeno dokazano da se ovaj model u praksi nije pokazao učinkovitim pa stoga njime nisu ostvareni ambiciozno najavljivani ciljevi tzv. tranzicijske pravednosti. Polazeći od svojih prijašnjih radova o retroaktivnosti zastarijevanja, koja je nespojiva $s$ mješovitom pravnom prirodom zastare kaznenog progona s pretežito materijalnopravnim obilježjima, autori u ovom radu raščlanjuju koncept nezastarijevanja ratnog profiterstva, njegovo značenje, doseg i učinkovitost. Također se bave pitanjem daljnje sudbine koncepta nezastarijevanja ratnog profiterstva i posljedicama koje je taj koncept prouzročio sustavu hrvatskog kaznenog pravosuda.

Ključne riječi: ratno profiterstvo, pretvorba i privatizacija, zastara, nezastarijevanje, načelo zakonitosti, načelo pravednosti, načelo učinkovitosti

\section{UVOD}

Prošlo je gotovo desetljeće od ustavnih promjena kojima je uvedeno nezastarijevanje ratnog profiterstva ${ }^{1}$ i donošenja Zakona o nezastarijevanju kaznenih djela ratnog profiterstva i kaznenih djela iz procesa pretvorbe i privatizacije (dalje u tekstu: Zakon o nezastarijevanju, Zakon ili ZON)², a polemike o opravdanosti, domišljenosti, normativnoj određenosti i ustavnopravnoj (i kaznenopravnoj) održivosti tih zahvata i dalje ne jenjaju. Na rubu prvog desetljeća postojanja ovih eksperimentalnih ustavnih i zakonskih presedana opravdano je zapitati se što je bio njihov željeni, a što je stvarni učinak? To je i nadalje predmet živih i katkad argumentiranih rasprava opće i stručne javnosti. Namjera nam je ovim radom pridonijeti toj raspravi podvrgavajući sam zakonski tekst (a neizravno i ustavni) testovima legaliteta (ustavnosti i zakonitosti donošenja i primjene) i efektiviteta (potrebe donošenja i učinkovitosti primjene). Pritom ove pojmove valja shvatiti i tumačiti in extenso - legalitet kao ocjenu (ne)poštovanja neprekoračivog minimuma temeljnih ustavnopravnih i kaznenopravnih načela (posebno lex praevia i lex certa), koja su dovedena u pitanje radi ostvarivanja "tranzicijske" pravednosti, a efektivitet kao ocjenu uspješnosti provedbe propisa koji su pompozno najavljivani kao svojevrsna panacea za ispravljanje "tranzicijskih nepravdi". Uz to, problematizirat ćemo i načelo pravednosti.

1 Ustavni zakon za provedbu Ustava Republike Hrvatske (Narodne novine, br. 121/2010) morao je biti donesen u roku od šest mjeseci od dana proglašenja Promjene Ustava (čl. 30. Promjene Ustava). Novoselec, P.; Novosel, D., Nezastarijevanje kaznenih djela ratnog profiterstva $i$ kaznenih djela iz procesa pretvorbe i privatizacije, Hrvatski ljetopis za kazneno pravo i praksu, vol. 18, br. 2, 2011 ., str. $604-605$.

2 Zakon o nezastarijevanju kaznenih djela ratnog profiterstva i kaznenih djela iz procesa pretvorbe i privatizacije, Narodne novine, br. 57/2011. 
No, prije no što započnemo testiranje, vratimo se na početak. Podsjetimo, najprije je 2010. godine izmijenjen članak 31. Ustava (načelo zakonitosti) ${ }^{3}$, i to proširenjem instituta nezastarijevanja kroz novi stavak 4. To je rezultiralo zakonodavnom reformom kaznenog prava donošenjem Zakona o nezastarijevanju ${ }^{4}$ i novog Kaznenog zakona (dalje u tekstu: KZ). ${ }^{5}$ Ratio legis donošenja ustavnih promjena $^{6}$ i Zakona bio je, prema obrazloženjima predlagatelja, omogućiti vraćanje protupravno stečene imovinske koristi tijekom procesa pretvorbe i privatizacije $^{7}$, Domovinskog rata te mirne reintegracije i imovinske koristi stečene ratnim profiterstvom. Iz obrazloženja ustavnih i zakonskih amandmana jasno

3 Ustav Republike Hrvatske, Narodne novine, br. 56/1990, 135/1997, 113/2000, 28/2001， 74/2010, 5/2014, http://www.usud.hr/uploads/Redakcijski\%20 prociscen $\% 20$ tekst $\% 20$ Ustava $\% 20$ Republike $\% 20$ Hrvatske, $\% 20$ Ustavni $\% 20$ sud\%20Republike\%20Hrvatske,\%2015.\%20sijecnja\%202014.pdf (25. srpnja 2019.). "Ne zastarijevaju kaznena djela ratnog profiterstva kao ni kaznena djela iz procesa pretvorbe i privatizacije u vrijeme Domovinskog rata i mirne reintegracije, ratnog stanja i neposredne ugroženosti neovisnosti i teritorijalne cjelovitosti države, propisana zakonom ili ona koja ne zastarijevaju prema međunarodnom pravu". Ustav je izmijenjen Odlukom objavljenom u Narodnim novinama br. 89/2010.

4 Kako navodi Derenčinović, pravna osnova za donošenje ZON-a bio je članak 5 . Promjene URH-a od 16. lipnja 2010. godine, kojim je u ustavni tekst ugrađena odredba o nezastarijevanju kaznenih djela ratnog profiterstva i kaznenih djela iz procesa pretvorbe i privatizacije, počinjenih u vrijeme Domovinskog rata i mirne reintegracije, ratnog stanja i neposredne ugroženosti neovisnosti i teritorijalne cjelovitosti države, propisana zakonom, ili ona koja ne zastarijevaju prema međunarodnom pravu (članak 31. stavak 4. URH-a). Na osnovi te ustavne promjene i Ustavnog zakona za provedbu URH-a u svibnju 2011. godine (Ustavni zakon za provedbu Ustava Republike Hrvatske, Narodne novine, br. 121/10) donesen je ZON koji je stupio na snagu 2. lipnja 2011. godine. Derenčinović, D., Doprinos Ustavnog suda Republike Hrvatske $u$ definiranju okvira za tumačenje ustavne odredbe o nezastarijevanju ratnog profiterstva $i$ kaznenih djela počinjenih u vrijeme pretvorbe i privatizacije, Sveske za javno pravo, vol. 21, br. 6., 2015., str. 7, http://www.fcjp.ba/templates/ja_avian_ii_d/ images/green/Sveske_za_javno_pravo_broj_21.pdf (4. srpnja 2019.).

5 Novi Kazneni zakon donesen je 2011. godine i imao je vacatio legis od dvije godine, tako da je stupio na snagu 2013. godine, Narodne novine, br. 125/2011, 144/2012, 56/2015, 61/2015, 101/2017, 118/2018.

6 O ustavnim promjenama 2010. pisao je i Kaleb. Vidi više u: Kaleb, Z., Ustavne promjene iz 2010 u odnosu na pravosude, Policija i sigurnost, vol. 19., br. 3, 2010., str. $345-353$.

7 Navedene pojmove pretvorbe i privatizacije definira Josipović u svojem članku te navodi određena istraživanja o privatizaciji. Josipović, I., Zastara u predmetima ratnog profiterstva $i$ kriminala u pretvorbi i privatizaciji i kontroverze nakon odluke Ustavnog suda $u$ predmetu Hypo, Hrvatski ljetopis za kaznene znanosti i praksu, vol. 25, br. 2, 2018., str. $199-205$. 
proizlazi da je riječ o protupravnoj imovinskoj koristi ostvarenoj kriminalnim aktivnostima koje nisu na vrijeme kazneno procesuirane. Cilj vraćanja te protupravno stečene imovinske koristi u državni proračun je indirektno i u funkciji osnaživanja nacionalnog gospodarstva. ${ }^{8}$

Prema Izvješću o radu na provedbi revizije pretvorbe i privatizacije ${ }^{9}$, koje je podneseno Hrvatskom saboru 2009. godine $^{10}$, u postupku pretvorbe i privatizacije prouzročen je gubitak od oko 16 milijardi kuna odnosno okvirno dvije milijarde eura. ${ }^{11}$ Josipović navodi kako "valja imati na umu da se podatak odnosi samo na tvrtke koje su bile obuhvaćene revizijom (njih oko polovina) te da je gubitak zapravo znatno veći"12 i "da procjene ekonomskih stručnjaka o izravnoj i neizravnoj šteti daleko nadmašuju ono što je na ograničenom broju slučajeva utvrdila državna revizija i dosežu čak 50 milijardi dolara.. ${ }^{13}$ Dakle, jasno je što je bio fokus i primarni cilj uvođenja koncepta nezastarijevanja ratnog profiterstva u hrvatski ustavni poredak i kazneno pravo - povrat sredstava pribavljenih kriminalnim aktivnostima, odnosno nerazmjerne imovinske koristi od počinjenja kaznenih djela koja zbog raznih razloga nisu dobila sudski epilog ubrzo nakon što su počinjena. Pitanje je, međutim, je li uvođenje tog koncepta bilo u skladu s temeljnim načelima hrvatskog kaznenog prava (načelo legaliteta) i, ne manje važno, jesu li rezultati kaznenog progona ratnog profiterstva u smislu utvrđivanja odgovornosti počinitelja i oduzimanja imovinske koristi u skladu s ambicioznim najavama (načelo efektiviteta)?

U kontekstu načela legaliteta, doseg koncepta nezastarijevanja ratnog profiterstva u znatnoj je mjeri ograničio Ustavni sud Republike Hrvatske koji je odlukom U-III-4149/2014 od 24. srpnja 2015. godine (u povodu ustavne tužbe u predmetu Hypo), u kojoj je istaknuto da je ona presedanskog značenja, protumačio da se ustavna novela odnosno ZON mogu primijeniti samo ako do stupanja na snagu te novele nije nastupila zastara kaznenog progona. Drugim riječima, Ustavni sud utvrdio je da je ustavna novela primjenjiva samo na one slučajeve u kojima do njezina stupanja na snagu nije nastupila zastara kaznenog

8 "Posebno za vraćanjem društvenoj zajednici protupravno pribavljene imovinske koristi učinjene tim djelima." Odluka Ustavnog suda U-III-4149/2014 od 24. srpnja 2015., str. 55, § 130.

9 Izvješće o radu na provedbi revizije pretvorbe i privatizacije, http://www.revizija.hr/ izvjesca/2007/revizije-pretvorbe-i-privatizacije/000-izvjesce_o_radu.pdf (6. ožujka 2019.).

10 Josipović, op. cit. u bilj. 7, str. $207-208$.

11 Izvješću o radu na provedbi revizije pretvorbe i privatizacije, op. cit. u bilj. 9, str. 23.

12 Josipović, op. cit. u bilj. 7, str. $207-208$.

13 Ibid. 
progona, a tu je okolnost potrebno utvrditi u svakom pojedinom slučaju. Time je najveći broj kaznenih postupaka pokrenutih odnosno vođenih primjenom koncepta nezastarijevanja ratnog profiterstva ozbiljno doveden u pitanje, što je rezultiralo i brojnim obustavama kaznenih postupaka, to jest donošenjem odbijajućih presuda (zbog zastare) (vidi infra pod 4.). U oštroj kritici te odluke Ustavnog suda isticalo se, među ostalim, da je njome taj Sud protuustavno (?!) "srušio" ustavnu novelu i odredbu o nezastarijevanju ratnog profiterstva učinio bespredmetnom. Najoštriji kritičari te odluke čak su predlagali da bi odluku trebalo ignorirati i nastaviti s kaznenim progonom i u onim slučajevima u kojima je nedvojbeno nastupila zastara kaznenog progona prije stupanja na snagu ustavne novele kako bi se Ustavnom sudu dala prilika da preispita svoje stajalište (!?).

Pritom se u potpunosti izgubilo iz vida da su i predlagatelji pokretanja postupka promjene Ustava (65 zastupnika u Hrvatskom saboru) u obrazloženju od 28. kolovoza 2007. godine (koje je poslužilo kao temelj izrade konačnog Prijedloga promjene Ustava iz 2010. godine) naveli da “...iz svega navedenog proizlazi da bi efekt predložene promjene Ustava bio sprječavanje nastupa zastare u svim predmetima u kojima zastara već nije nastupila ... primjena promjene na način da se uspostavi mogućnost kaznenog progona nakon što je zastara već nastupila ostaje na procjenu hrvatskih sudova (sudovi sude temeljem Ustava i zakona), a ovisit će i o odluci Europskog suda za ljudska prava ... sama predložena promjena, bez odgovarajuće interpretacije sudova ne daje konačni odgovor na to pitanje." Očito je, dakle, da su i sami predlagatelji bili svjesni ustavnopravnih dvojbi u vezi s primjenom ustavne novele zbog čega su tumačenje ovog pitanja ostavili sudovima (uključujući i Europski sud za ljudska prava, iz čega jasno proizlazi da su očekivali da se i Ustavni sud u određenom trenutku u povodu ustavne tužbe odredi prema dosegu i učincima ustavne novele kojom je uvedeno nezastarijevanje ratnog profiterstva). Stoga iznenađuje začuđenost korektivnom odlukom Ustavnog suda, za koju autori smatraju da je bila ispravna i u skladu $s$ načelom vladavine prava.

Ustavni sud u citiranoj je odluci tek na marginama otvorio i pitanje pravne prirode zastare kaznenog progona (materijalni, procesni ili mješoviti institut), no na njega nije dao odgovor. Autori smatraju da je riječ o mješovitom institutu s pretežito materijalnopravnim obilježjima na koji se odnose garancije sadržane $\mathrm{u}$ načelu zakonitosti, pa je $\mathrm{u}$ tom smislu svako retroaktivno propisivanje $\mathrm{i}$ primjena novih zastarnih rokova koji nisu bili na snazi tempore criminis povreda načela zakonitosti kao jednog od stožernih načela kaznenog prava. Argumente za svoje teze autori ističu u nizu radova i potkrjepljuju ih odredbama Ustava, Konvencije za zaštitu ljudskih prava i temeljnih sloboda, unutarnjeg zakonodav- 
stva, hrvatske kaznenopravne doktrine te sudske prakse nacionalnih sudova, Europskog suda za ljudska prava i Europskog suda. ${ }^{14}$

$\mathrm{S}$ obzirom na brojnost radova u kojima su autori istaknuli niz argumenata u potporu teze da je retroaktivno produljenje zastarnih rokova (što također uključuje i retroaktivno propisivanje nezastarijevanja) povreda načela zakonitosti (legaliteta), analiza ovog pitanja je ovom prigodom namjerno izostavljena (radi izbjegavanja nepotrebnog ponavljanja), no sve što je u citiranim radovima autora izneseno s tim u vezi vrijedi mutatis mutandis i u kontekstu ovoga rada. Dodatno na to, $\mathrm{u}$ nastavku rada bavimo se drugim aspektom načela legaliteta koji je relevantan za primjenu koncepta nezastarijevanja ratnog profiterstva, a to je zahtjev da zakon mora biti određen (lex certa). Nakon toga problematiziramo je li koncept nezastarijevanja ratnog profiterstva žrtvovao načelo zakonitosti radi ostvarivanja načela pravednosti i je li za to bilo valjanog (ustavno)pravnog uporišta (te je li uopće riječ o dva suprotstavljena ili pak komplementarna nadopunjujuća načela), a u konačnici ovaj sporni koncept podvrgavamo testu učinkovitosti (efektiviteta).

\section{ZADOVOLJAVA LI KONCEPT NEZASTARIJEVANJA RATNOG PROFITERSTVA, KAKO JE RAZRAĐEN ZAKONOM O NEZASTARIJEVANJU, ZAHTJEV NAČELA ZAKONITOSTI DA ZAKON MORA BITI ODREĐEN (LEX CERTA)?}

Na zastaru, koja je u hrvatskom kaznenom pravu institut mješovite pravne prirode s pretežito materijalnopravnim obilježjima, primjenjuje se načelo zakonitosti. Iz toga slijedi i da koncept nezastarijevanja ratnog profiterstva podliježe ocjeni o udovoljavanju svim zahtjevima načela zakonitosti - načelu da zakon mora biti pisan (lex scripta), da mora biti određen (lex certa), da se ne smije primjenjivati retroaktivno (lex praevia) te da ne smije koristiti analogiju (lex stricta).

U kontekstu zahtjeva da zakon mora biti određen (lex certa) Zakon o nezastarijevanju u članku 7. koristi izraz "nesrazmjerna" imovinska korist, odnosno navodi da će biti riječ o kaznenim djelima ratnog profiterstva ako je kaznenim

14 Za više vidi: Cvitanović, L., Aktualna problematika zastare u hrvatskom kaznenom zakonodavstvu, Hrvatski ljetopis za kazneno pravo i praksu, vol. 13, br. 2, 2006., str. 505 - 521; Derenčinović, op. cit. u bilj. 4; Dragičević Prtenjača M.; Vejnović A., Ratio legis zastare u kaznenom pravu s naglaskom na problematiku njezine pravne naravi, Godišnjak Akademije pravnih znanosti Hrvatske, vol. VII, br. 1, 2016., str. 94 - 141; Derenčinović, D.; Dragičević Prtenjača, M., Polemiziranje s odlukom Ustavnog suda u pogledu uskladenosti članka 86. Kaznenog zakona s Ustavom Republike Hrvatske, Odvjetnik, predano za objavu u broju 3/2019. 
djelima navedenima u čl. 2. - 6. toga Zakona ostvarena nerazmjerna imovinska korist, nakon čega slijedi opis radnji kojima se ta nerazmjerna imovinska korist mogla ostvariti (1. podizanjem cijena robe koja je u nestašici, 2. prodajom državne imovine znatno ispod njezine vrijednosti ili 3. na drugi način iskorištavanjem ratnog stanja i neposredne ugroženosti neovisnosti i teritorijalne cjelovitosti države $)^{15}$, ne navodeći ništa što bi barem približno odredilo vrijednost/visinu ostvarene imovinske koristi. Upravo ta odredba odiše nizom nejasnoća. U njoj se navodi "nesrazmjerna" imovinska korist, pa pitanje je koje se nameće $u$ odnosu na što? Ako je nerazmjerna, s čime se uspoređuje? Da bi nešto bilo nerazmjerno, mora postojati odnos, odnosno razmjer koji se vrednuje (kao npr. kod ugovaranja nerazmjerne imovinske koristi, pri čemu se jedna ugovorna strana stavlja u nepovoljniji položaj jer se obvezuje učiniti nešto što je u očitom nerazmjeru s protučinidbom druge ugovorne strane). Zakon na to pitanje ne daje nikakav odgovor i prepušta ga sudskoj praksi. Međutim, ovdje ne samo da je riječ o neodređenom ${ }^{16}$, normativnom obilježju kaznenog djela, nego o obilježju koje je faktično gotovo nemoguće odrediti, što odredbu čini izrazito nejasnom.

Druga nejasnoća koja proizlazi iz te odredbe, a proteže se na čitav Zakon o nezastarijevanju, jest da se "nesrazmjerna" imovinska korist izričito veže za kaznena djela ratnog profiterstva. Naime, Zakonom o nezastarijevanju regulirano je nezastarijevanje dviju skupina kaznenih djela - kaznenih djela ratnog profiterstva i kaznenih djela iz procesa pretvorbe i privatizacije, koja su počinjena, kako to izrijekom Zakon navodi, u vrijeme "Domovinskog rata i mirne reintegracije, ratnog stanja i neposredne ugroženosti neovisnosti i teritorijalne cjelovitosti države". Dakle, prema dikciji članka 7. ZON-a "nesrazmjerna” imovinska korist imala bi se utvrđivati samo u slučaju kaznenih djela ratnog profiterstva, a ne i u slučajevima kaznenih djela iz procesa pretvorbe i privatizacije, čime se dovodi $\mathrm{u}$ pitanje kriterij proporcionalnosti (razmjernosti), koji je jedan od (četiriju) dodatnih kriterija, uz kriterij trodijelnog testa ${ }^{17}$, koji je postavio Ustavni sud u odluci U-III-4149/2014. Za primjenu ZON-a, uz zadovoljenje tzv. trodijelnog

15 Čl. 7. st. 1. ZON-a.

16 Više o neodređenim vrijednostima kao obilježjima kaznenog djela vidi: Maršavelski, A., Neodređene ili određene vrijednosti kao obilježja kaznenih djela i sankcija u kaznenom pravu, Hrvatski ljetopis za kazneno pravo i praksu, vol. 16, br. 1, 2009., str. 117 146.

17 ZON bi se mogao primijeniti "samo (1.) ako je utvrđeno da postoji osnovana sumnja da su inkriminiranim ponašanjem ostvarena zakonska obilježja tog djela (npr. zlouporabe položaja i ovlasti iz članka 337. KZ97), (2.) da za to kataloško kazneno djelo u vrijeme stupanja na snagu Promjene URH iz 2010. godine nije nastupila zastara kaznenog progona i (3.) da su ostvarena dodatna obilježja iz članka 7. ZON-a". Derenčinović, op. cit. u bilj. 4, str. 13. 
testa $^{18}$, potrebno je još dodatno postojanje protektivnosti ${ }^{19}$, proporcionalnosti ${ }^{20}$, temporalnosti ${ }^{21}$ i koneksiteta ${ }^{22} \mathrm{ZON}-\mathrm{a}$, da bi se on mogao primijeniti. ${ }^{23}$ Kriterij proporcionalnosti, odnosno razmjernosti znači da se $\mathrm{ZON}$ primjenjuje samo na:

“... najteže oblike teških kaznenih djela kao i test usporedivosti kojim se nezastarijevanje kaznenih djela iz kataloga ZON čini ovisnim o težini kaznenog djela koja je u simboličkom smislu usporediva s kaznenim djelima koja ne zastarijevaju po međunarodnom pravu (genocid, ratni zločini i zločini protiv čovječnosti)." ${ }^{24}$

Dakle, ta kaznena djela moraju biti takvog stupnja težine koji bi odgovarao međunarodnim zločinima. Izostavljanje načela razmjernosti za kaznena djela iz procesa pretvorbe i privatizacije ostavlja mogućnost da se nezastarijevanje proširi i na ona kaznena djela koja po svojoj težini to ne opravdavaju, što je krajnje dvojbeno s ustavnopravnog (načelo razmjernosti), ali i kaznenopravnog motrišta (načelo ograničenja kaznenopravne prisile).

18 Više vidi u: Derenčinović, op. cit. u bilj. 4, str. 12 - 13.

19 Derenčinović navodi da kriterij protektivnosti ima izvorište u načelu zaštite javnog poretka. Stoga je postojanje razloga javnog poretka potrebno utvrditi u svakom konkretnom slučaju. Kriterij protektivnosti bit će zadovoljen ako su kaznenim djelom povrijeđeni fundamentalni interesi konkretne društvene zajednice. Derenčinović, op. cit. u bilj. 4, str. 13.

20 Primjena ZON-a ovisit će o tome jesu li određenom protupravnom radnjom ugroženi fundamentalni interesi konkretne društvene zajednice i je li riječ o najtežim oblicima teških kaznenih djela usporedivih s međunarodnim zločinima. Derenčinović, op. cit. u bilj. 4, str. 13.

${ }^{21}$ Kriterij temporalnosti zahtijeva da se činjenični opis na kojem se temelji određena pravna kvalifikacija mora odnositi na razdoblje na koje se primjenjuje ZON. ZON se može primijeniti ako je kazneno djelo počinjeno "u vrijeme Domovinskog rata i mirne reintegracije, ratnog stanja i neposredne ugroženosti neovisnosti i teritorijalne cjelovitosti države”. Derenčinović, op. cit. u bilj. 4, str. 13.

22 Mora postojati i koneksitet (povezanost). Za primjenu ZON-a nije dovoljno utvrditi da je kazneno djelo počinjeno u vrijeme Domovinskog rata i mirne reintegracije, ratnog stanja i neposredne ugroženosti neovisnosti i teritorijalne cjelovitosti države, već se traži postojanje i dodatne okolnosti da je ono počinjeno u procesu pretvorbe i privatizacije, odnosno da je riječ o tzv. ratnom profiterstvu. U kontekstu pretvorbe i privatizacije to znači da nije dovoljno "da je kazneno djelo iz kataloga počinjeno u vremenu pretvorbe i privatizacije, nego se traži da ono bude iz procesa pretvorbe i privatizacije, tj. da je počinitelj iskoristio taj proces za počinjenje djela". Derenčinović, op. cit. u bilj. 4, str. 14.

23 Ibid., str. 13.

24 Ibid., str. 13. 
Dodatno se postavlja pitanje zbog čega se taksativno navode kaznena djela u člancima 2. - 6. ZON-a (katalog kaznenih djela na koja se taj Zakon primjenjuje), kada se u članku 7. stavku 2. navodi da se "kaznenim djelima ratnog profiterstva smatraju i druga kaznena djela iz Osnovnog Krivičnog zakona Republike Hrvatske, Krivičnog zakona Republike Hrvatske i Kaznenog zakona, ako su počinjena pod okolnostima iz stavka l.” tog članka. Drugim riječima, prema stipulaciji tog stavka ZON se može primijeniti i na ostala kaznena djela koja nisu taksativno navedena u čl. 2. - 6. ako bi bila riječ o kaznenim djelima ratnog profiterstva kojima je ostvarena "nesrazmjerna" imovinska korist podizanjem cijena robe koja je u nestašici, prodajom državne imovine znatno ispod njezine vrijednosti ili na drugi način iskorištavanjem ratnog stanja i neposredne ugroženosti neovisnosti i teritorijalne cjelovitosti države. Čemu katalog kaznenih djela ako se drugom odredbom uvodi generalna klauzula nejasnog sadržaja i dosega? Konačno, ostaje nejasno, imajući u vidu ranije navedenu nekonzistentnu primjenu načela razmjernosti, odnosi li se generalna klauzula samo na kaznena djela ratnog profiterstva ili i na kaznena djela počinjena u procesu pretvorbe i privatizacije.

Sljedeća nejasnoća koja implicira pitanje usklađenosti koncepta nezastarijevanja ratnog profiterstva na način kako je razrađen Zakonom o nezastarijevanju s načelom zakonitosti (djelomično po osnovi lex certa, a djelomično po lex praevia) odnosi se na pravnu prirodu toga zakona (karakter zakona). Naime, razumijevanjem svih odredbi Zakona o nezastarijevanju proizlazi da je ZON temporalni, tj. kako to još Guastini naziva, privremeni zakon. ${ }^{25}$ Okolnost da je riječ o vremenskom zakonu ${ }^{26}$ njegovu retroaktivnu primjenu čini još spornijom $\mathrm{s}$ pozicije kaznenog materijalnog prava, ali i Ustava. Temporalnim (privremenim) zakonom uređuju se vremenski ograničeni odnosi koji postoje u vrijeme njegova donošenja. ${ }^{27}$ Glavna karakteristika vremenskih zakona jest da se prilikom

25 Guastini, R., Sintaksa prava, Naklada Breza, Zagreb, 2016., str. 293.

26 Burazin, Krešić i Tucak navode da se u kaznenom pravu rabi neprecizna terminologija kada se govori o "vremenskim zakonima", a zapravo je riječ o "tzv. privremenim normama (ili zakonima) (tal. leggi temporanee, engl. temporary statutes, njem. Zeitgesetze)". Burazin, L; Krešić, M.; Tucak, I., Priručnik za teoriju prava - praktični dio, Naklada Breza, Zagreb, 2018., str. 135, bilj. 21.

27 Više o vremenskim, privremenim, tj. temporalnim zakonima (njem. Zeitgesetze) vidi u: Roxin, C., Strafrecht, Allgemeiner Teil, Band I, München, 2006.; definiciju pojma Zeitgesetze na Rechtslexikon.net vidi na: http://www.rechtslexikon.net/d/ zeitgesetz/zeitgesetz.htm (19. ožujka 2019.).

Također o posebnosti vremenskih zakona govori i Frister, više u: Frister, H., Strafrecht, Allgemeiner Teil - Juristiche KurzLehrbücher, C. H. Beck, München, 2015., str. $62-63$. 
njihova donošenja već unaprijed zna da će biti privremeni i da će proizvoditi svoje učinke pro futuro, a nikako retroaktivno. ${ }^{28}$ I hrvatski zakonodavac je, kako bi se izbjegla različita tumačenja i shvaćanja, izričito propisao Kaznenim zakonom da će se "zakon koji je na snazi samo za određeno vrijeme primijeniti na kaznena djela počinjena u tom vremenu i nakon njegova prestanka važenja"29, a nikako da se smije primijeniti na događaje (kaznena djela) koji su se dogodili prije njegova stupanja na snagu. Vremenski zakoni mogu imati izričitu odredbu do kada su na snazi, na način da se izrijekom regulira vrijeme njihova važenja (primjerice Zakon o posebnom porezu na plaće, mirovine i druge primitke ${ }^{30}$, kolokvijalno poznat kao zakon o kriznom porezu) ${ }^{31}$ ili iz njihova sadržaja i svrhe može proizlaziti da se njima uređuju samo vremenski ograničeni odnosi. ${ }^{32} \mathrm{U}$ Zakonu o nezastarijevanju izrijekom je navedeno da se primjenjuje na kaznena djela počinjena u razdoblju Domovinskog rata i mirne reintegracije, ratnog stanja i neposredne ugroženosti neovisnosti i teritorijalne cjelovitosti države. ${ }^{33}$ Nedvojbeno je da se tim terminom određuje razdoblje primjene Zakona, koje je bilo prije njegova stupanja na snagu.

28 Jedna od njihovih osobitosti je i što se na njih ne primjenjuje načelo primjene (naj) blažeg zakona. Horvatić, Ž.; Derenčinović, D.; Cvitanović, L., Kazneno pravo opći dio 1 - kazneno pravo i kazneni zakon, Pravni fakultet Sveučilišta u Zagrebu, Zagreb, 2016., str. 148.

29 “Zakon koji je na snazi samo za određeno vrijeme primijenit će se na kaznena djela počinjena u tom vremenu i nakon njegova prestanka važenja ako zakonom nije drukčije propisano.", čl. 3. st. 5. KZ-a.

30 Zakon o posebnom porezu na plaće, mirovine i druge primitke (Narodne novine, br. 94/2009), koji se smatra temporalnim odnosno privremenim zakonom u užem smislu jer je njime izričito propisano da će se primjenjivati od dana stupanja na snagu (31. srpnja 2009.) do 31. prosinca 2010. godine.

31 Temporalnim zakonom smatrao se i Zakon o kaznenim djelima podrivačke terorističke djelatnosti protiv državnog suvereniteta i teritorijalne cjelovitosti Republike Hrvatske iz 1992., Narodne novine, br. 74/1992; https://narodne-novine.nn.hr/ clanci/sluzbeni/1992_11_74_1964.html (29. ožujka 2019.). Zakon je bio donesen s ciljem popunjavanja pravne praznine do donošenja novog Kaznenog zakona 1997. godine. Znači, bio je donesen kako bi se privremeno uredili odnosi koji su postojali u vrijeme njegova donošenja iako se nigdje u njegovim odredbama ne nalazi izričita odredba o vremenu njegova važenja.

32 Temporalni ili vremenski zakoni su zakoni koji sadržavaju izričitu odredbu do kada su na snazi (vremenski zakoni u užem smislu), odnosno na koji se period imaju primijeniti, ali i zakoni iz čijeg se sadržaja i svrhe može utvrditi da se njima uređuju vremenski ograničeni odnosi (vremenski zakoni u širem smislu). Više vidi u: Horvatić et al., op. cit. u bilj. 28, str. 148.

33 Čl. 1. ZON-a. 
Ustavni sud u svojoj je odluci u povodu ustavne tužbe u predmetu Hypo otišao korak dalje i točno odredio razdoblje na koje se ima primijeniti Zakon o nezastarijevanju. Utvrdio je da je razdoblje primjene Zakona o nezastarijevanju od 30. svibnja 1990. do 15. siječnja 1998. godine. ${ }^{34}$ Ustavni sud tim je potezom samo konkretizirao razdoblje "Domovinskog rata i mirne reintegracije, ratnog stanja i neposredne ugroženosti neovisnosti i teritorijalne cjelovitosti države". ${ }^{35}$ Tako je Zakon o nezastarijevanju postao temporalni zakon u užem smislu, i to $s$ izričitom retroaktivnom primjenom. ${ }^{36}$ Da Ustavni sud to nije učinio, opet bi bila riječ o temporalnom zakonu, samo u širem smislu. Za razliku od autora ZON-a koji su smatrali da je "dovoljno da zakonski tekst upućuje na okolnosti koje omogućuju sudovima pobliže utvrđenje tog vremena, što Zakon o nezastarijevanju i čini” ${ }^{37}$, Ustavni sud zauzeo je stav "da načelo pravne sigurnosti objektivnog pravnog poretka i načela pravne određenosti i predvidljivosti kaznenih djela i kazni zahtijevaju precizno kalendarsko određenje tog razdoblja, a ono je osobito važno i za sudsku praksu, nužno je razdoblje, koje je u novom stavku 4. članka 31. Ustava određeno opisno"38, pa je precizirao to razdoblje.

Da je ZON vremenski zakon, potvrđuju i autori Burazin, Krešić i Tucak, koji navode da su "norme Zakona o nezastarijevanju kaznenih djela ratnog profiterstva i kaznenih djela iz procesa pretvorbe i privatizacije prijelazne norme koje otpočetka imaju vremenski ograničen rok sposobnosti djelovanja jer se člankom 1. navedenog Zakona određuje da se mogućnost poduzimanja kaznenog progona i nakon isteka rokova za zastaru kaznenog progona odnosi na kaznena djela ratnog profiterstva i kaznena djela iz procesa pretvorbe i privatizacije počinjena $\mathrm{u}$ određenom vremenskom razdoblju, tj. u vrijeme Domovinskog rata i mirne reintegracije, ratnog stanja i neposredne ugroženosti neovisnosti i teritorijalne cjelovitosti države". ${ }^{39}$

Zakonom o nezastarijevanju privremeno se uređuju odnosi, ali ne oni koji su postojali u vrijeme njegova donošenja, već oni koji su nastali mnogo prije nego li je taj Zakon bio donesen. Donošenjem i primjenom takvog atipičnog

34 Odluka Ustavnog suda U-III-4149/2014, str. 43, § 99.

35

36

\section{Čl. 1. ZON-a.}

Dragičević Prtenjača; Vejnović, op. cit. u bilj. 14, str. 122.

Novoselec; Novosel, op. cit. u bilj. 1, str. 613.

Odluka Ustavnog suda U-III-4149/2014, str. 43, § 84.

"Takve se prijelazne norme još nazivaju i tzv. privremenim normama". Burazin et al., op. cit. u bilj. 26, str. 135.

Sinonimi za prijelazne, odnosno privremene norme su još prolazne i nestalne, odnosno one koje imaju vremenski ograničenu sposobnost djelovanja. Više vidi u: Guastini, op. cit. u bilj. 25, str. 293. 
temporalnog zakona narušava se pravna sigurnost jer primjena ZON-a implicira retroaktivnost, i to na odnose koji su nastali od 12 do 20 godina prije njegova donošenja. Valja podsjetiti da je Venecijanska komisija u Izvješću o vladavini prava konstatirala kako je pravna sigurnost temelj povjerenja građana u pravosudni sustav i vladavinu prava te da zakoni moraju biti predvidivi u svojim učincima. ${ }^{40}$

\section{JE LI UVOĐENJEM KONCEPTA NEZASTARIJEVANJA RATNOG PROFITERSTVA ŽRTVOVANO NAČELO ZAKONITOSTI RADI OSTVARIVANJA NAČELA PRAVEDNOSTI I JE LI ZA TO BILO (USTAVNO)PRAVNOG UPORIŠTA?}

Kao opravdanje za promjenu Ustava i donošenja Zakona o nezastarijevanju u literaturi je često istican argument pravednosti. U podlozi takvog shvaćanja je davanje prevage načelu pravednosti $\mathrm{i}^{41}$ ili, kako u Ustavu stoji, načelu "socijalne pravde" pred načelom zakonitosti, omogućavanjem procesuiranja kaznenih djela retroaktivnim ukidanjem zastare za tzv. privatizacijska kaznena djela i kaznena djela ratnog profiterstva. Na prvi pogled takvim rezoniranjem dolaze u koliziju dva ustavna načela - načelo pravednosti s načelom zakonitosti (jednim od temeljnih načela kaznenog prava). Suštinsko pitanje koje se nameće glasi: Kojemu načelu dati prednost? Načelu zakonitosti ili načelu pravednosti? Je li uopće riječ o dvama suprotstavljenim ili pak komplementarnim ustavnim načelima?

Neki autori u svojim ranim radovima (napisanim u suautorstvu) naglašavaju da je ta polemika bespredmetna jer smatraju da "Ustav ne krši tu odredbu (načela zakonitosti, op. a.), jer je djelo bilo kažnjivo i u trenutku kad je počinjeno" te se ne propisuje niti primjenjuje teža kazna "od one koja je bila primjenjiva u času kad je kazneno djelo počinjeno" te da se "hrvatskom ustavotvorcu ne može odreći pravo da pobliže odredi povratno djelovanje kaznenog zakona, a time i sadržaj i opseg načela zakonitosti”. ${ }^{42}$ Međutim, u nekim kasnijim rado-

40 Više vidi u: Izvješće Venecijanske komisije o vladavini prava iz 2011.; European Commission for Democracy through Law (Venice Commission) Report on the Rule of Law, § 44; https://www.venice.coe.int/WebForms/documents/default. aspx?pdffile=CDL-AD(2011)003rev-e (7. ožujka 2019.).

41 Vladin Prijedlog odluke o pristupanju promjeni Ustava RH, rujan 2009.

42 Novoselec; Novosel, op. cit. u bilj. 1, str. 609. Novoselec i Novosel idu čak toliko daleko da smatraju kako se i kaznena djela za koja je u postupku bila donesena odbijajuća presuda zbog zastare ponovno procesuiraju na temelju Zakona o nezastarijevanju te da se u tim slučajevima neće raditi o povredi načela ne bis in idem, sve u skladu sa zauzetim stavom da se može procesuirati i za ona kaznena djela za koja je zastara nastupila. Ibid., str. 611. 
vima (napisanim u suautorstvu s drugim autorima) ti isti autori ističu da radi važnosti kaznenog progona pretvorbenog kriminala prednost valja dati načelu pravednosti. ${ }^{43}$ Postoje i autori koji tvrde da je koncept nezastarijevanja ratnog profiterstva "dio narativa tranzicijske pravde", odnosno jedan od njezinih mehanizama kojim bi se trebala ispraviti nepravda koju su uzrokovali "nepravedni" zakoni doneseni u tranzicijskom razdoblju. U tom bi kontekstu, ističe se, valjalo dati primat načelu pravednosti pred načelom zakonitosti. ${ }^{44}$

Čak i da se shvati na taj način, tj. kao jedan od mehanizama kojim se reagira na tranzicijsko zakonodavstvo $\mathrm{u}$ primjeni $\mathrm{u}$ vrijeme pretvorbe, privatizacije, Domovinskog rata i $\mathrm{dr}^{45}$, potrebno je podsjetiti na pravo značenje pojma tzv. tranzicijske pravde, kako je ono formulirano u ustavnosudskoj praksi nekih

43 Novoselec, P.; Roksandić Vidlička, S.; Maršavelski, A., Retroactive prosecution of transitional economic crimes in Croatia - testing the legal principles and human rights, $\mathrm{u}$ : Van Erp, J.; Huisman, W.; Walle, G. V. (ur.), The Routledge Handbook of White-Collar and Corporate Crime in Europe, Routledge, London, New York, 2015., str. 198 - 217; Roksandić Vidlička, S., Possible Future Challenge for the ECtHR?: Importance of the Act on Exemption and the Sanader Case for Transitional Justice Jurisprudence and the Development of Transitional Justice Policies, Zbornik Pravnog fakulteta u Zagrebu, vol. 64, br. 5-6, 2014., str. 1091 - 1119; Josipović, op. cit. u bilj. 7, str. 197 - 259.

44 Roksandić Vidlička, S., Tranzicijska pravda kao metoda ostvarenja ustavnih vrednota uz analizu prakse Europskog suda za ljudska prava i odluke Ustavnog suda u predmetu Hypo, u: Turković, K.; Munivrana Vajda, M.; Dragičević Prtenjača, M. (ur.), Liber amicorum Petar Novoselec - Kazneno pravo: sinergija teorije i prakse, Zbornik radova u čast profesora Petra Novoselca, Pravni fakultet Sveučilišta u Zagrebu, Zagreb, 2019., str. 436.

45 Više o tranziciji vidi u: United Nations Human Rights (UNHR), The Office of the United Nations High Commissioner for Human Rights Transitional Justice and Economic, Social and Cultural Rights, United Nations publication; 2014., https:// www.ohchr.org/Documents/Publications/HR-PUB-13-05.pdf (27. ožujka 2019.); The International Center for Transitional Justice; dostupno na: https://www.ictj. org/about/transitional-justice (26. ožujka 2019.); Roksandić Vidlička, S., Prosecuting Serious Economic Crimes as International Crimes - A New Mandate for the ICC?, Duncker \& Humblot, Berlin, 2017., str. 189 - 279; Dolezal, D., Organized Crime and Corruption in Croatia - A Criminological View, u: Stoychev, S. P. (ur.), Organized Crime and the Balkan Political Context, Risk Monitor Foundation Edition, Sofia, 2010., str. 59 61, https://www.researchgate.net/profile/Dalibor_Dolezal/publication/269628803 Organized_Crime_and_Corruption_in_Croatia_-_A_Criminolgical_View/links/ 549004320cf214269f26463b/Organized-Crime-and-Corruption-in-Croatia-A-Criminolgical-View.pdf (26. ožujka 2019.); Freeman, M., Truth Commissions and Procedural Fairness, Cambridge University Press, Cambridge, 2006., http://assets.cambridge. org/97805216/15648/frontmatter/9780521615648_frontmatter.pdf (26. ožujka 2019.); Teitel, R. G., Transitional Justice Genealogy, Harvard Human Rights Journal, vol. 16, 2003., str. 69 - 94; https://www.qub.ac.uk/Research/GRI/mitchell-institute/ FileStore/Filetoupload,757186,en.pdf (12. srpnja 2019.). 
europskih država i Europskog suda za ljudska prava. Tako je, primjerice, načelu pravednosti dana prednost u njemačkom kaznenom pravu, primjenom tzv. Radbruchove formule zbog počinjenih zločina od strane njemačke vlasti i države (DDR) koja je bila utemeljena na nepravu (Unrechtsstaat). ${ }^{46}$ Pozitivni zakoni tog društvenog uređenja bili su, kako to Radbruch ističe, suprotni temeljnim načelima vladavine prava, ljudskim pravima i pravednosti jer su upravo ti zakoni bili kriminalni, arbitrarni i stvarali/podržavali državu odnosno vladavinu neprava. ${ }^{47}$ U tim slučajevima bila je riječ o zločinima, tj. o zločinima protiv čovječnosti, ratnim zločinima i zločinima protiv mira ${ }^{48}$, koji su najteža kaznena djela, među ostalim i s najtežim propisanim kaznama. ${ }^{49}$

46 Više vidi u: Roksandić Vidlička, op. cit. u bilj. 45, str. 189 - 279.

47 Više vidi u: Radbruch, G., Statutory Lawlessness and Supra-Statutory law, Oxford Journal of Legal Studies, vol. 26, br. 1, 1946., translated by Paulson, B. L., 2006., str. 5 - 6, http://news.twelvetribes.org/wp-content/uploads/2014/05/1946-Radbruch Statutory-Lawlessness-and-Supra-Statutory-Law.pdf (18. ožujka 2019.).

48 Genocida nije bilo tada, nego se sudilo za zločine protiv mira, više vidi u: Novoselec, P.; Bojanić, I., Opći dio kaznenog prava, Pravni fakultet Sveučilišta u Zagrebu, Zagreb, 2013., str. 515 i Munivrana Vajda, M., Međunarodni zločini prema novom Kaznenom zakonu, Hrvatski ljetopis za kazneno pravo i praksu, vol. 19, br. 2, 2012., str. 819 - 842; Munivrana Vajda, M.; Namačinski, M., Zločin protiv čovječnosti kao izraz državne politike, Godišnjak Akademije pravnih znanosti Hrvatske, vol. VII, br. I, 2016., str. 142 - 185; Munivrana Vajda, M., Genocid u svjetlu općih instituta materijalnog kaznenog prava, doktorska disertacija branjena na Pravnom fakultetu Sveučilišta u Zagrebu, Zagreb, 2011., str. 13.

49 Zločin se definira kao najteže kazneno djelo, Hrvatski jezični portal, http://hjp. znanje.hr/index.php?show=search (18. ožujka 2019.). Zločini bi bila teška kaznena djela koja izvorište nalaze u međunarodnom pravu i toliko su teški, odnosno impliciraju veću količinu neprava od drugih kaznenih djela reguliranih Kaznenim zakonom. Više o pojmu zločina vidi u: Munivrana Vajda, Genocid u svjetlu..., op. cit. u bilj. 48, str. 13 - 16; Munivrana Vajda, Međunarodni zločini... op. cit. u bilj. 48, str. 819 - 820. Oni bi se od drugih kaznenih djela trebali razlikovati kako na kvalitativnoj osnovi tako i na kvantitativnoj osnovi. Kvalitativna osnova bila bi ta veća količina neprava, a kvantitativna bi se ogledala u zapriječenoj kazni. Za sve "zločine" u hrvatskom kaznenom pravu danas je propisana kao najteža kazna kazna dugotrajnog zatvora. Vidi genocid (čl. 88. KZ-a), zločin agresije (čl. 89. KZ-a), zločin protiv čovječnosti (čl. 90. KZ-a), ratni zločin (čl. 91. KZ-a). Horvatić, Ž.; Novoselec, P., Kazneno pravo - Opći dio, MUP, Zagreb, 1999., str. 8. Posebna vrsta zločina je i genocid koji je i prema mišljenju mnogih najteže kazneno djelo, a o kojem je kao zločinu nad zločinima pisao Schabas, W. A., Genocide in International Law - The Crimes of Crimes, Cambridge University Press, 2000., https://www.javeriana.edu.co/blogs/ildiko/files/ Genocide-in-International-Lawl.pdf (18. ožujka 2019.). 
S druge strane kaznena djela navedena u čl. 2. - 6. Zakona o nezastarijevanju, koliko god imala utjecaj na gospodarstvo tog vremena (s reperkusijama i u današnje vrijeme), ipak nisu tog stupnja težine, niti je njihovo nepravo takvog opsega da bi bila bliska međunarodnim zločinima. ${ }^{50}$ Tvrdnja da bi u tranzicijskim društvima, poput hrvatskog, trebalo dati prevagu tako (pogrešno) shvaćenom načelu pravednosti pred načelom zakonitosti ${ }^{51}$, i to samo zbog toga što je ono prolazilo kroz proces tranzicije, nije utemeljena iz nekoliko razloga. Radbruchova formula se ponajprije odnosila na pravo propisano zakonima jer ti zakoni nisu bili u skladu s općim načelima i vladavinom prava, pa tek onda na njihovu primjenu. U Hrvatskoj se tzv. pretvorbeni kriminal događao 90-ih godina prošlog stoljeća, kada su na snazi bili zakoni koji možda jesu jednim dijelom bili problematični u primjeni već zbog okolnosti da su naslijeđeni (preuzeti) iz bivše državne zajednice (bivša SFRJ nije bila stranka Konvencije za zaštitu ljudskih prava i temeljnih sloboda) i transplantirani u novi hrvatski ustavnopravni poredak, no koji ni po čemu nisu usporedivi sa zakonima države neprava kakva je bila bivša DDR. Problem hrvatske pretvorbe i privatizacije društvenih poduzeća, dakle, nije bio u samom karakteru i sadržaju relevantnog zakonodavstva (daleko od tog da je ono bilo idealno, ali sasvim sigurno nije odražavalo obilježja države neprava kao što je to bio slučaj u bivšem DDR-u), već u njegovoj selektivnoj i nekonzistentnoj primjeni. Dakle, u Hrvatskoj nije bila riječ o tome da je zakonodavstvo koje je tada bilo na snazi bilo u suprotnosti s vladavinom prava, niti je riječ o tome da se zakonodavstvo koje je bilo u skladu s vladavinom prava tumačilo i provodilo suprotno vladavini prava, nego je jednostavno bila riječ o tome da se ono iz raznih razloga (faktično ratno stanje, stanje okupacije trećine hrvatskog državnog teritorija, kadrovski problemi i odljev velikog broja kvalitetnih pravosudnih dužnosnika, (pre)opterećenost u radu pravosuđa i sl.) nije na odgovarajući način primjenjivalo, odnosno da se primjenjivalo selektivno i na temelju kriterija koji nisu bili jasno definirani. ${ }^{52}$

Razvidno je kako je velika razlika u socijalnom kontekstu između primjene Radbruchove formule u njemačkom društvu u odnosu na situaciju u hrvatskom

50 Bili bi zločini iznimno, kako Roksandić Vidlička navodi, ako se razmatraju kao kaznena djela zločina protiv čovječnosti ili ratnih zločina, ali tada uopće ne bi bilo potrebno donošenje Zakona o nezastarijevanju. Roksandić Vidlička, Possible Future Challenge..., op. cit. u bilj. 43, str. 1109.

51 Roksandić Vidlička, op. cit. u bilj. 44.

52 Više o zakonima u vrijeme DDR-a te o načinu na koji su se zakoni tumačili i provodili vidi u: Derenčinović, D., U povodu presude Europskog suda za ljudska prava u predmetu Streletz, Kessler i Krenz protiv Njemačke, Hrvatski ljetopis za kazneno pravo u praksu, vol. 8, br. 2., 2001., str. 147 - 170. 
društvu koja se nastojala riješiti uvođenjem koncepta nezastarijevanja ratnog profiterstva. Dakle, argument da je hrvatsko društvo bilo tranzicijsko društvo, pa se danas zbog toga može primijeniti korektivna i pogrešno shvaćena inačica načela pravednosti koje bi imalo primat pred načelom zakonitosti nije pravno, ni sociološki opravdan. Smatramo da tadašnje stanje zakonodavstva i prakse nije opravdavalo intervenciju u temeljne postulate države, kao što je to učinjeno ustavnim promjenama i ZON-om. Točno je, kao što je ranije navedeno, da je zbog niza razloga od kojih su neki bili povezani s tranzicijom, a drugi s faktičnim ratnim stanjem, okupacijom dijela državnog teritorija, tektonskim poremećajima i kadrovskim problemima u pravosuđu i sl. funkcioniranje države bilo dijelom otežano, no tvrdnja da je tadašnja država bila u potpunosti disfunkcionalna kao država neprava koja je podržavala kriminal njegovim namjernim neprocesuiranjem nije samo neosnovana, već je i opasna iz perspektive temelja hrvatske državnosti. Valja u tom smislu podsjetiti da se kaznenim pravom koje se temelji na zakonima koji su u skladu s temeljnim ustavnim načelima, načelom socijalne pravde ili načelom pravednosti te vladavinom prava, ne smije manipulirati jer upravo takve manipulacije dovode do kršenja svih navedenih načela. Povijest (kaznenog prava) je bremenita primjerima kojima su se pozivanjem na načelo pravednosti (bez utvrđivanja njegova stvarnog sadržaja) ostvarivale još dublje nepravde od onih koje su se izvanrednim rješenjima represivno-reparativne prirode nastojale otkloniti. Takve situacije nisu nepoznate ni kroz povijest kaznenog prava koje se primjenjivalo u Hrvatskoj. Valja se u tom smislu prisjetiti Zakona o krivičnim djelima protiv naroda i države koji je u tadašnjoj državi (DFJ) donesen ubrzo nakon završetka II. svjetskog rata s ciljem obračuna s kolaboracionistima, "narodnim neprijateljima" i protivnicima režima. Uz najoštrije sankcioniranje kaznenih djela među kojima su i verbalni delikti, ograničenje prava na žalbu i drugih prava obrane u hitnom postupku i sl., taj zakon po nekim segmentima svog narativa, ali i po nekim pragmatičnim pravnim rješenjima, vrlo nalikuje ustavnim promjenama i ZON-u jer je u članku 16. propisivao (također retroaktivno) nezastarijevanje kataloških kaznenih djela. Danas se to može činiti ne samo anakronim nego i suprotnim temeljnim načelima ustava i međunarodnog prava (u tom je smislu na temelju odredaba Zakona o kaznenom postupku donesen i niz tzv. revizijskih presuda), no u ono vrijeme to je prikazano kao pravedno, napredno, svrsishodno i učinkovito.

Osim toga, važno je podsjetiti i na to da se načelo pravednosti odnosi na cjelokupni pravni poredak, odnosno na socijalnu pravdu u društvu, i u tom kontekstu može se govoriti o načelu pravednosti u širem smislu, dok se načelo zakonitosti odnosi na kazneno pravo i lex specialis je u odnosu na sva druga načela proklamirana Ustavom. Sva ustavna načela koja se nalaze u Ustavu i razrađuju zakonima moraju biti u skladu s načelom pravednosti. U svim demokratskim 
društvima u kojima se poštuju ljudska prava i vladavina prava to i jest slučaj, pa je i načelo zakonitosti ne samo u skladu s načelom pravednosti nego upravo počiva na načelu pravednosti. Primjerice, u Italiji je to regulirano čl. 25. st. 2. talijanskog Ustava ${ }^{53}$, u Francuskoj čl. 8. Ustava ${ }^{54}$, dok je u Njemačkoj to načelo regulirano čl. 103. st. 2. Temeljnog zakona Savezne Republike Njemačke. ${ }^{55}$ Tako je u rješenju Drugog senata Savezne Republike Njemačke od 24. listopada $1996 .{ }^{56}$ navedeno da je zabrana retroaktivne primjene zakona iz čl. 103. st. 2. Temeljnog zakona "apsolutna i ispunjava svoju funkciju jamstva pravne države i temeljnih prava kroz striktnu formalizaciju". ${ }^{57}$ Također je navedeno da je "striktna zabrana retroaktivne primjene zakona iz čl. 103. st. 2. Temeljnog zakona s gledišta pravne države opravdana posebnom osnovom povjerenja na kojima počivaju kazneni zakoni, ako ih je usvojio demokratski zakonodavac koji ima obvezu poštovanja temeljnih prava". ${ }^{58}$

Stoga je dilema o tome kojemu načelu treba dati prednost u osnovi pogrešna jer je riječ o dvama nerazdruživim načelima koja su u samim temeljima ustavnog uređenja. Načelom zakonitosti ostvaruje se i načelo socijalne pravde jer je pravedno da nitko ne bude kažnjen niti procesuiran za kazneno djelo koje nije bilo kao takvo utvrđeno zakonom u vrijeme njegova počinjenja, niti se na njega može primijeniti novi zakon koji nije blaži, pa se njime osigurava i vladavina prava. $\mathrm{U}$ tom kontekstu načelo zakonitosti ne bi se smjelo relativizirati stavljanjem $\mathrm{u}$ odnos s drugim načelima, kao niti davati prevagu bilo kojem drugom ustavnom načelu. Načelo zakonitosti od iznimne je važnosti za kazneno pravo. Njime se kroz pravnu predvidivost omogućuje pravna sigurnost, čime se osigurava vladavina prava. Ono je od donošenja Ustava Republike Hrvatske 1990. godine načelo koje je potpuno u skladu s načelom socijalne pravde i vladavine prava.

53 Ustav Republike Italije, http://www.jus.unitn.it/dsg/pubblicazioni/costituzione/ costituzione\%20genn2008eng.pdf (20. ožujka 2019.).

54 “... and no one may be punished except by virtue of a Law drawn up and promulgated before the offense is committed, and legally applied.” Čl. 8. francuskog Ustava (France's Constitution of 1958 with Amendments through 2008), https://www. constituteproject.org/constitution/France_2008.pdf?lang=en (20. ožujka 2019.).

55 Temeljni zakon Savezne Republike Njemačke (Basic Law for the Federal Republic of Germany), Deutscher Bundestag, Berlin, 2018., https://www.btg-bestellservice. de/pdf/80201000.pdf (20. ožujka 2019.).

56 Rješenje Drugog senata od 24. listopada 1996., 2 BvR1851, 1853, 1875 i 1852/94. Zern, T.; Bauch, M. (ur.), Izbor odluka Ustavnog suda Savezne Republike Njemačke, Konrad Adenauer Stiftung, Zagreb, 2015., str. 290.

57 Ibid., str. 290.

58 Ibid., str. 290. 
Načelo zakonitosti zajamčeno je i čl. 7. Europske konvencije za zaštitu ljudskih prava i temeljnih sloboda (dalje u tekstu: EKLJP) ${ }^{59}$ i ono se svrstava u nederogabilna prava ${ }^{60}$, uz bok pravu na život (čl. 2. EKLJP-a), zabrani mučenja (čl. 3. EKLJP-a) i zabrani ropstva i prisilnog rada (čl. 4. EKLJP-a). U pravu su autori koji posebno ističu njegovu važnost, koju "naglašava i činjenica da derogacija tog jamstva nije dopuštena na temelju članka 15 . Konvencije čak ni u vrijeme rata ili drugog izvanrednog stanja koje ugrožava opstanak nacije". ${ }^{61}$

U uređenim pravnim sustavima utemeljenima na vladavini prava i demokratskom uređenju načelo pravednosti u kaznenom pravu može se i mora tumačiti isključivo u povezanosti s načelom zakonitosti. Ono se mora kretati unutar granica načela zakonitosti kao njegova dopuna i pozitivno se s njim preklapati (komplementarnost) u smislu da kaznena djela moraju biti propisana zakonom, i to u vrijeme počinjenja djela (lex scripta), da je zabranjena retroaktivna primjena zakona na djela koja prije donošenja zakona nisu bila propisana kao kaznena djela (lex praevia), da sve norme zakona zadovoljavaju načelo određenosti (lex certa) te da je zabranjena analogija (lex stricta), i da se to treba ostvarivati na način koji jamči ostvarivanje pravednosti u najširem smislu te riječi. S obzirom na intrinzičnu povezanost i međusobnu uvjetovanost te komplementarnost načela zakonitosti i načela pravednosti valja demistificirati (namjerno postavljenu) pogrešnu dilemu navedenu u naslovu ovog poglavlja i konstatirati da je koncept nezastarijevanja ratnog profiterstva i njegova razrada u $\mathrm{ZON}$-u ne samo u suprotnosti s načelom legaliteta (zakonitosti) već i s načelom pravednosti.

59 Za više o dosegu značenja odredbe čl. 7. ELJKP-a vidi ESLJP-ov Guide on Article 7 of the European Convention on Human Rights, str. 9, § 16. i 17.; https://www.echr. coe.int/Documents/Guide_Art_7_ENG.pdf (22. ožujka 2019.).

60 Više o nederogabilnim pravima vidi u: Koji, T., Emerging Hierarchy in International Human Rights and Beyond: From the Perspective of Non-Derogable Rights, European Journal of International Law, vol. 12, br. 5, 2001., str. 917, http://www.ejil.org/ article.php?article $=1555 \&$ issue $=38$ i http://www.ejil.org/pdfs/12/5/1555.pdf $(20$. ožujka 2019.).

${ }_{61}$ Krstulović Dragičević, A., Načelo zakonitosti u praksi Europskog suda za ljudska prava, Hrvatski ljetopis za kaznene znanosti i praksu, vol. 23, br. 2, 2016., str. 405. Doduše, postoji iznimka od njegove primjene, i to čak i onda kada djelo nije bilo kazneno djelo po nacionalnom pravu u vrijeme njegova počinjenja, ali je "predstavljao kazneno djelo u skladu s općim načelima prava priznatim od civiliziranih naroda". Čl. 7. st. 2. EKLJP-a. 


\section{PROLAZI LI KONCEPT NEZASTARIJEVANJA RATNOG PROFITERSTVA TEST UČINKOVITOSTI?}

Nakon što smo utvrdili da je uvođenjem koncepta nezastarijevanja ratnog profiterstva u hrvatsko kazneno pravo na više razina došlo do povrede načela legaliteta kao jednog od temeljnih ustavnih i kaznenopravnih načela, ali isto tako i načela pravednosti, valja se zapitati je li prema načelu finis sanctificat media (cilj opravdava sredstvo) to bilo svrsishodno (oportuno), odnosno učinkovito (efektivno). Postojala su velika očekivanja šire i dijela stručne javnosti u vezi s tim eksperimentalnim zahvatima, pa neki autori navode da "javnost očekuje da će nakon izmjene Ustava doći do značajnih promjena u progonu pretvorbenog i privatizacijskog kriminala". ${ }^{62}$ Je li se to uistinu ostvarilo?

Još u vrijeme neposredno nakon ustavnih promjena i donošenja ZON-a autori ovoga rada isticali su da je u vezi s temeljnim ciljem ZON-a, tj. povrata "nesrazmjerne" imovinske koristi realno očekivati da te imovine više nema zbog dugog proteka vremena od počinjenja kaznenih djela do njihova procesuiranja. Jednako je tako vjerojatno da nema ni imovine koja porijeklo ima u tim kaznenim djelima, a vrlo je vjerojatno da ni druge osobe na koje je ona eventualno bila prenesena također više ne posjeduju tu imovinu. Ako opet možda i postoji, autori su stava da kazneno pravo nije odgovarajuće rješenje za njihovo vraćanje. Mnogo prikladnije bilo bi postupanje kroz druge grane prava, primjerice, porezno pravo. ${ }^{63}$ Čak je vrlo vjerojatno da se takvim rješenjem ne bi kršila načela poreznog prava, niti bi ono zahtijevalo ustavne promjene i druge intervencije u temeljne postulate vladavine prava. Naš je stav da i "danas prema Općem poreznom zakonu ${ }^{64}$ postoji obveza plaćanja poreza i na stjecanje bez pravne osnove, tj. na "prihod, dohodak, dobit ili drugu procjenjivu korist ostvarenu bez pravne osnove ${ }^{765}$, odnosno i na nezakonito stečene prihode". ${ }^{66}$ To se rješenje moglo primijeniti i u kontekstu ratnog profiterstva, tj. u svim onim

62 Novoselec; Novosel, op. cit. u bilj. 1, str. 603, 604.

63 Primjerice razrezivanjem veće stope poreza za imovinu čija pravna osnova stjecanja je upitna ili sumnjiva, ili nema pravne osnove, koja odredba postoji i danas u OPZ-u, iako je vrlo sporno njezino postojanje.

64 Opći porezni zakon, Narodne novine, br. 115/2016, 106/2018.

65 Čl. 11. st. 2. OPZ-a: "Ako je prihod, dohodak, dobit ili druga procjenjiva korist ostvarena bez pravne osnove, porezno tijelo utvrdit će poreznu obvezu u skladu s posebnim zakonom kojim se uređuje pojedina vrsta poreza.".

66 Glavina, D.; Dragičević Prtenjača, M., Kazneno djelo utaje poreza kao oblik porezne evazije s posebnim osvrtom na poslovanje putem poreznih utočišta, Godišnjak Akademije pravnih znanosti Hrvatske, vol. IX, br. 1, 2018., str. 181. 
situacijama u kojima je protupravno ostvarena "nesrazmjerna" imovinska korist. Nepobitna je i činjenica da se primjenom Zakona o nezastarijevanju samo gomilaju troškovi vođenja postupka za kaznena djela za koja je dokazivanje otežano i za koja postupci, prema recentnim godišnjim izvješćima Državnog odvjetništva Republike Hrvatske (dalje u tekstu: DORH) u sve većem broju završavaju negativnim odlukama.

Da je primjena Zakona o nezastarijevanju vrlo problematična, ističu i neki proponenti uvođenja koncepta nezastarijevanja ratnog profiterstva, koji navode da u kaznenim postupcima koji se vode primjenom $\mathrm{ZON}$-a nedostaju dokazi, mnoge kompanije (društva) više ne postoje, a financijska dokumentacija je uništena ili nije dostupna iz drugih razloga. Zanimljivo je da i ti autori, poučeni negativnim iskustvima iz prakse, danas ističu da takve ex post facto intervencije dovode do pravne nesigurnosti. ${ }^{67}$ Upravo su teškoće u dokazivanju kod teoretičara i praktičara koji zastaru smatraju primarno procesnim institutom i inače jedan od argumenata protiv nezastarijevanja kaznenih djela. Tako jedan autor navodi da su protiv nezastarijevanja bili i oni teoretičari koji su davali zastari primarno procesni karakter, argumentirajući svoja stajališta da "protiv nezastarijevanja govori iskustvo, teškoće dokazivanja, opasnost od pogrešnih odluka pa zato razlozi pravne sigurnosti čine osnovu koja opravdava zastaru". ${ }^{68}$ Utoliko više nije jasno zbog čega je problematika tzv. ratnog profiterstva regulirana na način za koji se od početka moglo jasno vidjeti da će, uz to što je načelno neprihvatljiv, biti i praktično neprovediv.

O učinkovitosti primjene ZON-a svjedoče i izvješća Državnog odvjetništva Republike Hrvatske. Tako je u Izvješću za 2016. godinu navedeno kako je broj negativnih odluka

“...rezultat prethodno naznačenih problema necjelovitosti, nedostupnosti i/ili nepostojanja dokumentacije, uz protek vremena koji znatno utječe na vjerodostojnost iskaza potencijalnih svjedoka, nastup smrti u odnosu na dio terećenih počinitelja kao i ranije pobliže navedena odluka Ustavnog suda i

67 Roksandić Vidlička, op. cit. u bilj. 45, str. 116. Navodi i kako je upitno može li se takav zakon smatrati adekvatnim i učinkovitim rješenjem za borbu protiv gospodarskih kaznenih djela. "On the other hand, it is questionable whether the introduction of new legal instruments, like those adopted in Croatia more than 20 years after the privatization had started, or more than 10 years after the Homeland war and peaceful integration had ended, could be considered an adequate and effective approach to combat transitional economic crimes and confiscate illegally obtained assets". Roksandić Vidlička, Possible Future Challenge..., op. cit. u bilj. 43, str. 1116.

68 Bačić, F., Kazneno pravo opći dio, Informator, Zagreb, 1998., str. 480 - 481. 
u toj odluci izraženi stavovi o članku 7. Zakona i institutu zastare razlozi su zbog kojih izostaje uspješnost u do sada pokrenutim postupcima te se i nadalje ne bilježe pravomoćno uspješno okončani postupci u odnosu na značajnije predmete procesuirane primjenom ovog Zakona" ${ }^{69}$

Zaključuje se kako "nije izgledno da bi daljnjim protekom vremena bilo opravdano očekivati značajnije pozitivne pomake i rezultate $u$ procesuiranju ovih kaznenih djela kakvi su se predviđali i očekivali prilikom donošenja samog Zakona". ${ }^{70}$

U izvješću DORH-a za 2017. navedeno je da

“...zbog znatnog proteka vremena nije raspoloživa (u cijelosti ili pretežitom dijelu) financijska dokumentacija niti druga relevantna dokumentacija čija analiza bi omogućavala vjerodostojnu rekonstrukciju događaja, uz praćenje tijeka novca, na osnovu kojih bi se s dostatnom razinom izvjesnosti za osudu počinitelja ovih djela, moglo zaključivati o kaznenim djelima. Dakle, u pravilu, nisu raspoloživi dostatni materijalni dokazi, a protek vremena negativno se odražava i na tzv. personalne dokaze, odnosno kvalitetu svjedočkih iskaza budući je dio svjedoka preminuo ili zbog životne dobi nije u mogućnosti okolnosno i vjerodostojno i/ili uopće relevantno rekonstruirati zbivanja i o njima iskazivati. Zbog navedenog i nadalje je kod primjene ovog Zakona uočeno da prevladavaju tzv. negativne odluke". ${ }^{71}$

Iz posljednjeg dostupnog Izvješća DORH-a za 2018. godinu ${ }^{72}$ proizlazi da je donesena “jedna prvostupanjska osuđujuća presuda u predmetu Hypo (nakon što je prethodna pravomoćna presuda $u$ tom predmetu na ponovno prvostupanjsko suđenje upućena Ustavnom odlukom)", ali da se "nastavlja s donošenjem pravomoćnih negativnih odluka te je i u ovom izvještajnom razdoblju uslijedilo donošenje takvih odluka u pet predmeta". ${ }^{73}$ Prema prikazanom, činjenica je

69 Izvješće DORH-a za 2016., str. 97, http://www.dorh.hr/IzvjesceDrzavnogOdvjetnistvaRepublikeHrvatskeZa (12. ožujka 2019.).

Više o tome o kojem je broju predmeta riječ vidi Izvješće DORH-a za 2018., str. 139 - 140; Izvješće DORH-a za 2017., str. 103 - 104; Izvješće DORH-a za 2016., str. $96-97$.

70 Izvješće DORH-a za 2016., str. 97.

71 Izvješće DORH-a za 2017., str. 103, http://www.dorh.hr/dorh07062018 (12. ožujka 2019.).

72 Izvješće DORH-a za 2018., str. 139 - 140, http://www.dorh.hr/dorh03052019 (13. kolovoza 2019.).

73 Od toga je jedna presuda bila oslobađajuća zbog nedostatka dokaza, a četiri su negativne odluke uslijedile zbog zastare i/ili zaključka o neispunjavanju obilježja zahtijevanih čl. 7. Zakona, dakle, primjenom pravnih shvaćanja iz Ustavne odluke. 
da faktično izostaje uspješnost "u postupcima na koje se primjenjuje Zakon te se ne bilježe pravomoćno uspješno okončani postupci u odnosu na značajnije predmete procesuirane primjenom ovog Zakona". ${ }^{74} \mathrm{U}$ tom smislu DORH nastavlja i dalje, navodeći da je

“...kraj takvog stanja stvari, malo izgledno, i unatoč nesmanjenom trudu državnog odvjetništva na procesuiranju ratnih profitera i osoba koje su počinile kaznena djela u procesu pretvorbe i privatizacije, da bi daljnjim protekom vremena bilo opravdano očekivati značajnije pozitivne pomake i rezultate u procesuiranju ovih kaznenih djela kakvi su se predviđali i očekivali prilikom donošenja samog Zakona". 75

Također, nigdje ne nailazimo na podatke (primjerice u izvješćima Državnog zavoda za statistiku) o tome koliko je oduzeto protupravne imovinske koristi, a kako iz citiranih izvješća DORH-a proizlazi da prevladavaju "negativne odluke", to bi značilo da nije oduzeto gotovo ništa, čime je učinkovitost uvođenja koncepta nezastarijevanja ratnog profiterstva ozbiljno dovedena u pitanje. I ne samo to. Očito je da su, zbog svih donesenih negativnih odluka, troškovi vođenja takvih postupaka pali isključivo na teret državnog proračuna, odnosno, u konačnici, svih poreznih obveznika. Osim toga, kako su nakon citirane odluke Ustavnog suda u predmetu Hypo gotovo svi relevantni akteri u većini postupaka koji su na to morali paziti po službenoj dužnosti jer je riječ o povredi zakona (zamjenici državnih odvjetnika, suci istrage i optužna vijeća), pritom neskriveno ignorirajući tu odluku i sam Ustav (vjerojatno iz bojazni da ih se ne etiketira zbog opstrukcije), zanemarivali okolnost da je u tim postupcima nastupila zastara kaznenog progona prije no što je ustavna novela stupila na snagu (pa i na višekratno isticanje prigovora zastare okrivljenika i njihovih obrana), postavlja se pitanje eventualnih financijskih i inih implikacija pokretanja postupka ustavnosudske zaštite, odnosno postupka pred Europskim sudom za ljudska prava zbog povrede prava na pravično suđenje. Dakako, još teže od financijskih mogle bi po državu biti reputacijske implikacije ovog nedomišljenog i neuspjelog eksperimenta.

\section{ZAKLJUČAK}

Pokušaji da se promjenom Ustava Republike Hrvatske iz 2010. godine i Zakonom o nezastarijevanju isprave "tranzicijske nepravde" prouzročene ratnim

Izvješće DORH-a za 2018., str. 140.

74 Izvješće DORH-a za 2017., str. 104.

75 Izvješće DORH-a za 2018., str. 140. 
profiterstvom i kaznenim djelima počinjenim u procesu pretvorbe i privatizacije ostali su posve jalovi, ali su prouzročili znatnu štetu, čiji će razmjeri biti potpuno vidljivi tek kroz neko vrijeme. Omogućavanjem retroaktivnog procesuiranja kaznenih djela iz procesa pretvorbe i privatizacije te ratnog profiterstva za koja zastara nije nastupila (nakon ustavne odluke /U-III-4149/2014/), koja su počinjena prije okvirno 21 - 29 godina, prekršeno je stožerno načelo kaznenog materijalnog prava (načelo zakonitosti - zabrana retroaktivnosti koja se odnosi na produljene zastarne rokove kao i na temporalnost Zakona o nezastarijevanju te načelo određenosti zakona) kao i nekoliko drugih važnih ustavnih načela (načelo jednakosti i pravednosti), što je rezultiralo negativnim posljedicama za stanje u kaznenom pravosuđu, osobito iz rakursa percepcije javnosti o učinkovitosti rada pravosuđa.

U kaznenom pravu načelo zakonitosti jedno je od temeljnih načela (primjerice prema EKLJP-u načelo zakonitosti smatra se nederogabilnim pravom), koje jamči ostvarivanje vladavine prava i poštovanje ljudskih prava. U radu je elaborirano kako se načelo zakonitosti ima primijeniti i na zastaru te njezino naličje - nezastarijevanje, pa se time na Zakon o nezastarijevanju primjenjuje zabrana retroaktivnosti (lex praevia) te načelo određenosti zakona (lex certa). Načelo zakonitosti s jedne strane štiti od arbitrarnog postupanja nadležnih tijela (zakonodavca kao donositelja norme te pravosuđa, tj. sudova i državnog odvjetništva kao primjenjivača norme), dok s druge strane predstavlja okosnicu postupanja tih tijela pri provođenju i primjeni zakona iz kaznenog materijalnog prava. Narušavanjem tog načela uvođenjem koncepta nezastarijevanja ratnog profiterstva u hrvatsko pravo ne samo da su dovedeni u pitanje postulati pravne države utemeljene na vladavini prava, nego je zbog nedorečenosti i nejasnoća implementacijskog zakonodavstva (Zakon o nezastarijevanju), koje ne udovoljava načelu lex certa, nastala situacija u praksi da nadležna pravosudna tijela, kako tijela progona tako i sud, nisu bila sigurna u kojim situacijama i na koja kaznena djela primijeniti taj zakon. Time su dovedena u pitanje ustavna načela jednakosti i pravednosti. Očito je da zagovornici rješenja koje je bez presedana u suvremenom komparativnom kaznenom pravu nisu uzeli u obzir okolnost da se naknadnim "ispravljanjem" nečega što se dogodilo prije gotovo $21-29$ godina (ili 20 godina od donošenja Zakona o nezastarijevanju), odnosno zakasnjelim provođenjem pravde, događa upravo suprotno - dolazi do nepravde. Takvo rezoniranje potvrdila je i Venecijanska komisija, koja je u predmetu provođenja lustracije u Mađarskoj zaključila da zbog znatnog proteka vremena zakasnjelim provođenjem prava i pravde dolazi do suprotnog efekta, čime se krši načelo pravednosti.

Tako nastalo stanje ima i daljnje negativne posljedice. Posljednji izvještaji DORH-a upućuju na zaključak da je uvođenje koncepta nezastarijevanja ratnog 
profiterstva, a posebno način na koji je to razrađeno implementacijskim zakonodavstvom, potpuni promašaj. Gotovo svi postupci u kojima je primijenjen Zakon o nezastarijevanju završili su pravomoćnim negativnim odlukama. To u konačnici znači da se prvotna ideja o oduzimanju "nesrazmjerne" imovinske koristi nije realizirala. Dakle, efikasnost Zakona kao instrumenta za "ispravljanje" nepravde podbacila je, pa je time relativizirana svrha njegova donošenja s aspekta oportuniteta, ali i načela pravednosti. Istodobno, cjelokupni je teret tih postupaka pao na teret državnog proračuna, a realno je očekivati i daljnje negativne financijske i reputacijske implikacije po eventualnim tužbama zbog povrede prava na pravično suđenje.

\section{LITERATURA}

Bačić, F., Kazneno pravo opći dio, Informator, Zagreb, 1998.

Burazin, L; Krešić, M.; Tucak, I., Priručnik za teoriju prava- praktični dio, Naklada Breza, Zagreb, 2018.

Cvitanović, L., Aktualna problematika zastare u hrvatskom kaznenom zakonodavstvu, Hrvatski ljetopis za kazneno pravo i praksu, vol. 13, br. 2, 2006., str. 505-521.

Derenčinović D.; Dragičević Prtenjača M., Polemiziranje s odlukom Ustavnog suda u pogledu usklađenosti članka 86. Kaznenog zakona s Ustavom Republike Hrvatske, Odvjetnik, predano za objavu u broju 3/2019.

Derenčinović, D., Doprinos Ustavnog suda Republike Hrvatske u definiranju okvira za tumačenje ustavne odredbe o nezastarijevanju ratnog profiterstva $i$ kaznenih djela počinjenih u vrijeme pretvorbe i privatizacije, Sveske za javno pravo, vol. 21., br. 6., 2015., str. 7-14.

Derenčinović, D., U povodu presude Europskog suda za ljudska prava u predmetu Streletz, Kessler i Krenz protiv Njemačke, Hrvatski ljetopis za kazneno pravo u praksu, vol. 8., br. 2, 2001., str. 147-170.

Doležal, D., Organized Crime and Corruption in Croatia- A Criminological View, u: Stoychev, S. P. (ur.), Organized Crime and the Balkan Political Context, Risk Monitor Foundation Edition, Sofia, 2010., str. 59-71.

Dragičević Prtenjača M.; Vejnović A., Ratio legis zastare u kaznenom pravu s naglaskom na problematiku njezine pravne naravi, Godišnjak Akademije pravnih znanosti Hrvatske, vol. VII, br. 1, 2016., str. 94-141.

Freeman, M., Truth Commissions and Procedural Fairness, Cambridge University Press, Cambridge, 2006.

Frister, H., Strafrecht, Allgemeiner Teil,- Juristiche Kurz- Lehrbücher, C.H.Beck, München, 2015. 
Glavina, D.; Dragičević Prtenjača, M., Kazneno djelo utaje poreza kao oblik porezne evazije s posebnim osvrtom na poslovanje putem poreznih utočišta, Godišnjak Akademije pravnih znanosti Hrvatske, vol. IX, br. 1, 2018., str. 175-208.

Guastini, R., Sintaksa prava, Naklada Breza, Zagreb, 2016.

Horvatić, Ž.; Derenčinović, D.; Cvitanović, L., Kazneno pravo opći dio I- kazneno pravo i kazneni zakon, Pravni fakultet Sveučilišta u Zagrebu, Zagreb, 2016.

Horvatić, Ž.; Novoselec, P., Kazneno pravo- Opći dio, MUP, Zagreb, 1999.

Josipović, I., Zastara u predmetima ratnog profiterstva $i$ kriminala u pretvorbi i privatizaciji i kontroverze nakon odluke Ustavnog suda u predmetu Hypo, Hrvatski ljetopis za kaznene znanosti i praksu, vol. 25, br. 2, 2018., str. 197-259.

Kaleb, Z., Ustavne promjene iz 2010 u odnosu na pravosude, Policija i sigurnost, vol. 19., br. 3, 2010., str. 345-353.

Koji, T, Emerging Hierarchy in International Human Rights and Beyond: From the Perspective of Non-Derogable Rights, European Journal of International Law, vol. 12, br. 5, 2001., str. 917-941.

Krstulović Dragičević, A., Načelo zakonitosti u praksi Europskog suda za ljudska prava, Hrvatski ljetopis za kaznene znanosti i praksu, vol. 23, br. 2, 2016., str. 403-433.

Maršavelski, A., Neodređene ili određene vrijednosti kao obilježja kaznenih djela i sankcija u kaznenom pravu, Hrvatski ljetopis za kazneno pravo i praksu, vol. 16, br. 1, 2009., str. 117-146.

Munivrana Vajda, M., Genocid u svijetlu općih instituta materijalnog kaznenog prava, doktorska disertacija branjena na Pravnom fakultetu Sveučilišta u Zagrebu, Zagreb, 2011.

Munivrana Vajda, M., Međunarodni zločini prema novom Kaznenom zakonu, Hrvatski ljetopis za kazneno pravo i praksu, vol. 19., br. 2, 2012., str. 819-842.

Munivrana Vajda, M.; Namačinski, M., Zločin protiv čovječnosti kao izraz državne politike, Godišnjak Akademije pravnih znanosti Hrvatske, vol. VII, br. I, 2016., str. 142- 185.

Novoselec, P.; Bojanić, I., Opći dio kaznenog prava, Pravni fakultet Sveučilišta u Zagrebu, Zagreb, 2013.

Novoselec, P.; Novosel, D., Nezastarijevanje kaznenih djela ratnog profiterstva i kaznenih djela iz procesa pretvorbe i privatizacije, Hrvatski ljetopis za kazneno pravo i praksu, vol. 18., br. 2, 2011., str. 603-619.

Novoselec, P.; Roksandić Vidlička, S.; Maršavelski, A., Retroactive prosecution of transitional economic crimes in Croatia - testing the legal principles and human rights, u: Van Erp, J.; Huisman, W.; Walle, G. V. (ur.), The Routledge Handbook 
of White-Collar and Corporate Crime in Europe, Routledge, London, New York, 2015., str. 198-217.

Radbruch, G., Statutory Lawlessness and Supra-Statutory law, Oxford Journal of Legal Studies, vol. 26, br. 1, 1946., translated by Paulson, B. L., 2006., str. 5-6, http://news.twelvetribes.org/wp-content/uploads/2014/05/1946-Radbruch_Statutory-Lawlessness-and-Supra-Statutory-Law.pdf (18. ožujka 2019.).

Roksandić Vidlička, S., Possible Future Challenge for the ECtHR?: Importance of the Act on Exemption and the Sanader Case for Transitional Justice Jurisprudence and the Development of Transitional Justice Policies, Zbornik Pravnog fakulteta $\mathrm{u}$ Zagrebu, vol. 64, br. 5-6, 2014., str. 1091-1119.

Roksandić Vidlička, S., Prosecuting Serious Economic Crimes as International Crimes - A New Mandate for the ICC?, Duncker \& Humblot, Berlin, 2017.

Roksandić Vidlička, S., Tranzicijska pravda kao metoda ostvarenja ustavnih vrednota uz analizu prakse Europskog suda za ljudska prava i odluke Ustavnog suda u predmetu Hypo, u: Turković, K.; Munivrana Vajda, M.; Dragičević Prtenjača, M. (ur.), Liber amicorum Petar Novoselec- Kazneno pravo: sinergija teorije i prakse, Zbornik radova u čast profesora Petra Novoselca, Pravni fakultet Sveučilišta u Zagrebu, Zagreb, 2019.

Roxin, C., Strafrecht, Allgemeiner Teil, Band I, C.H. Beck, München, 2006.

Schabas, W. A., Genocide in International Law - The Crimes of Crimes, Cambridge University Press, Cambridge, 2000.

Teitel, R. G., Transitional Justice Genealogy, Harvard Human Rights Journal, vol. 16., 2003., str. 69-94.

\section{PROPISI}

France's Constitution of 1958 with Amendments through 2008, https://www.constituteproject.org/constitution/France_2008.pdf?lang=en (20. ožujka 2019.).

Kazneni zakon, Narodne novine, br. 125/2011, 144/2012, 56/2015, 61/2015, 101/2017, 118/2018.

Opći porezni zakon, Narodne novine, br. 115/2016, 106/2018.

Temeljni zakon Savezne Republike Njemačke (Basic Law for the Federal Republic of Germany) Deutscher Bundestag, Berlin 2018., https://www.btg-bestellservice.de/pdf/80201000.pdf (20. ožujka 2019.).

Ustav Republike Hrvatske, Narodne novine, br. 56/1990, 135/1997, 113/2000, 28/2001, 74/2010, 5/2014.

Ustav Republike Italije; http://www.jus.unitn.it/dsg/pubblicazioni/costituzione/ costituzione\%20genn2008eng.pdf (20. ožujka 2019.). 
Ustavni zakon za provedbu Ustava Republike Hrvatske, Narodne novine, br. $121 / 2010$.

Zakon o kaznenim djelima podrivačke terorističke djelatnosti protiv državnog suvereniteta i teritorijalne cjelovitosti Republike Hrvatske iz 1992. god., Narodne novine, br. 74/1992.

Zakon o nezastarijevanju kaznenih djela ratnog profiterstva i kaznenih djela iz procesa pretvorbe i privatizacije, Narodne novine, br. 57/2011.

Zakon o posebnom porezu na plaće, mirovine i druge primitke, Narodne novine, br. $94 / 2009$.

\section{IZVJEŠĆA I ODLUKE}

Izvješće Državnog odvjetništva Republike Hrvatske za 2016. godinu Izvješće Državnog odvjetništva Republike Hrvatske za 2017. godinu Izvješće Državnog odvjetništva Republike Hrvatske za 2018. godinu

Izvješće o radu na provedbi revizije pretvorbe i privatizacije, http://www.revizija. $\mathrm{hr} /$ izvjesca/2007/revizije-pretvorbe-i-privatizacije/000-izvjesce_o_radu.pdf (6. ožujka 2019.).

Izvješće Venecijanske komisije o vladavini prava iz 2011; European Commission for Democracy through Law (Venice Commission) Report on the Rule of Law, § 44; https://www.venice.coe.int/WebForms/documents/default.aspx?pdffile $=$ CDL-AD(2011)003rev-e (7. ožujka 2019.).

Odluka Ustavnog suda U-III-4149/2014, od 24. srpnja 2015.

Rješenje Drugog senata od 24. listopada 1996.- 2 BvR1851, 1853,1875 i 1852/94. Izbor odluka Ustavnog suda Savezne Republike Njemačke, urednici: Tobias Zern, Martin Bauch, Konrad Adenauer Stiftung, Zagreb, 2015.

The International Center for Transitional Justice; dostupno na: https://www. ictj.org/about/transitional-justice (26. ožujka 2019.).

United Nations Human Rights (UNHR), The Office of the United Nations High Commissioner for Human Rights Transitional Justice and Economic, Social and Cultural Rights, United Nations publication; 2014, https://www. ohchr.org/Documents/Publications/HR-PUB-13-05.pdf (27. ožujka 2019.). 
Summary

\section{Leo Cvitanović* \\ Davor Derenčinović ** \\ Marta Dragičević Prtenjača***}

\section{EXEMPTION FROM THE STATUTE OF LIMITATIONS FOR WAR PROFITEERING IN THE 'JAWS' OF THE PRINCIPLES OF LEGALITY, JUSTICE, AND EFFICIENCY}

An exemption from the statute of limitations for war profiteering and criminal offences committed during privatization was introduced in the Croatian legal system by constitutional amendments in 2010. As a follow-up, the pertinent act (Law on Exemption) was adopted in 2011. These novelties with retroactive effect were unprecedented not only in Croatian but also in comparative law. They have also sparked numerous controversies among scholars. The proponents of these changes emphasized that their purpose was to correct the injustices that had led to the non-prosecution of war profiteering and privatization crimes. On the other hand, the opponents, including the authors of this paper, emphasized that such a method of correcting "transitional injustice" was wrong. They believed this solution to be contrary to the principle of legality (prohibition of ex post facto legislation, the requirement of the clarity of law), the principle of justice and principle of efficiency. This paper analyzes the concept of retroactive statute of limitations exemption for war profiteering, its meaning, scope, and effectiveness. The authors address the issue of future development of this concept as well as the consequences that it has had for the Croatian criminal justice system.

Keywords: war profiteering, privatization, statute of limitations, exemption from the statute of limitations, principle of legality, principle of justice, principle of efficiency

* Leo Cvitanović, Ph. D, Professor, Faculty of Law, University of Zagreb, Trg Republike Hrvatske 14, Zagreb; leocvitanovic@gmail.com;

ORCID ID: orcid.org/0000-0001-8383-5262

** Davor Derenčinović, Ph. D, Professor, Faculty of Law, University of Zagreb, Trg Republike Hrvatske 14, Zagreb; president of the Croatian Academy of Legal Sciences, Trg Republike Hrvatske 14, Zagreb; davorderen@yahoo.com; ORCID ID: orcid.org/0000-0002-4146-7905

*** Marta Dragičević Prtenjača, Ph. D., Assistant Professor, Faculty of Law, University of Zagreb, Trg Republike Hrvatske 14, Zagreb; marta.dragicevic@pravo.hr; ORCID ID: orcid.org/0000-0001-9666-4765 